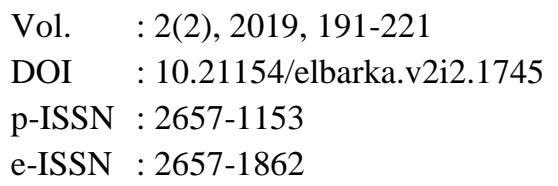

\title{
URGENSI PENERAPAN SISTEM EKONOMI ISLAM
}

\section{Fahrurrozi}

Institut Agama Islam Negeri Madura

email: sahabatululalbab@gmail.com

\begin{abstract}
The ideology of capitalism cannot be separated from the understanding of European liberalism that occurred in the 18th century, where capitalism and liberalism were born in response to the dictatorship of the feudal lords and the church at that time. Meanwhile, the emergence of socialism in the 19th century, could not be separated from the role of Karl Marx who wrote a book The Communist Manifesto of a German socialist figure who had contributed in the revival of the union and unity of the workers and intellectuals who had more than a century been amputated by market mechanisms. The Islamic economic system regulates all economic activities, so that humans as economic agents cannot be free as freely as possible, there are limits set in the Koran and Hadith, all the objectives of economic activity cannot be separated from Islamic values, making and selling illicit goods such as alcohol is not permissible in Islamic economics. The Islamic economic system is not only used as an alternative economic system but is a solution of various economic problems today.
\end{abstract}

الملخص: لا يمكن فصل أيديولوجية الرأسمالية عن مفهوم الليير الية الأوروبية التي

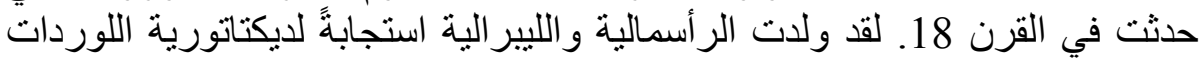

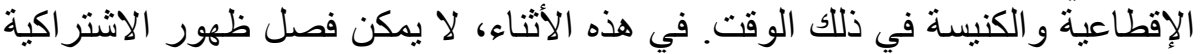

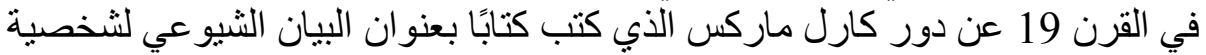

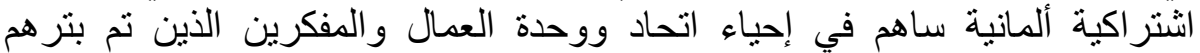

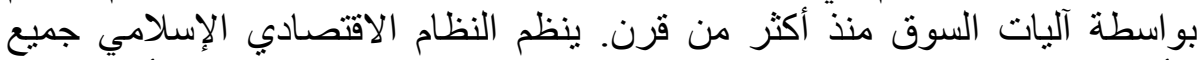

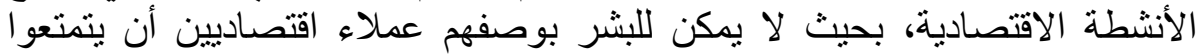




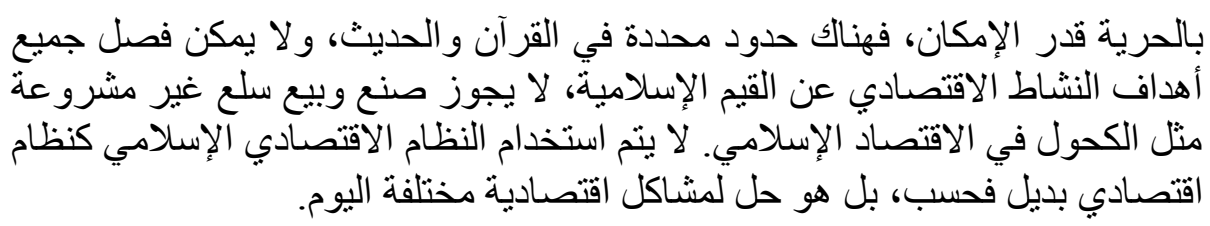

Abstrak: Ideologi kapitalisme tidak bisa dipisahkan dari paham liberalisme eropa yang terjadi pada abad ke 18, dimana kapitalisme dan liberalisme lahir sebagai respon atas diktatorisme para kaum feodal dan gereja waktu itu. Sementara itu kemunculan sosialisme pada abad ke 19, tidak lepas dari peranan Karl Marx yang menulis sebuah buku The Communist manifesto seorang tokoh sosialis Jerman yang telah memberikan sumbangsih dalam kebangkitan persatuan dan kesatuan kalangan buruh dan intelektual yang sudah lebih dari seabad diamputasi oleh mekanisme pasar. Sistem ekonomi Islam mengatur seluruh aktifitas ekonomi, sehingga manusia sebagai pelaku ekonomi tidak bisa bebas sebebas-bebasnya, ada batasan-batasan yang sudah diatur dalam al-Qur'an dan Hadits, seluruh tujuan aktifitas ekonomi tidak bisa di pisahkan dengan nilai-nilai Islam, membuat dan menjual barang-barang haram seperti alcohol tidak diperbolehkan dalam ekonomi Islam. Sistem ekonomi Islam bukan hanya dijadikan sebagai sistem ekonomi alternate tapi menjadi solusi dari berbagai permasalahan ekonomi saat ini.

Keywords: Ekonomi Kapitalis, Ekonomi Sosialis, Ekonomi Islam

\section{PENDAHULUAN}

Sistem ekonomi merupakan institusi sosial yang beroperasi menggunakan sumber daya yang sudah tersedia dan sekaligus begian dari sistem sosial yang bertugas dan berfungsi sebagai landasan pijak untuk menjawab masalah-masalah pokok ekonomi seperti: produksi, distribusi, dan konsumsi.

Dalam perekonomian dunia ada tiga sistem ekonomi yang dikenal, yaitu ekonomi kapitaslis, ekonomi sosialis, dan ekonomi 
Islam. Dari berbagai system ekonomi tersebut antara satu sitem dengan system yang lainnya mempunyai cir-ciri tersendiri. Kapitalis muncul sekitar abad ke 16 yang dianggap gagal dalam mensejahterakan rakyat, sehinga dengan kegagalan tersebut memunculkan sistem ekonomi baru yang disebut dengan sistem ekonomi sosialis, dimana sistem ekonomi sosialis di gadang-gadang sebagai sistem yang dapat memperbaiki dan bahkan di anggap lebih baik dari sistem ekonomi kapitalis, akan tetapi sistem ekonomi sosialis ternyata gagal karena menimbulkan kesengsaraan pada rakyat yang diakibatkan oleh ulah para pemerintahnya.

Pasca perang dunia II perkembangan Negara-negara Islam meningkat signifikan yang merupakan Negara bekas jajahan imperialis. Keberadaan Negara-negara Islam tersebut meningkatkan gairah masyarakat untuk mengubah haluan dan mencari solusi alternative agar jalannya perekonomian berjalan sesuai dengan harapan, disinilah ekonomi Islam hadir yang dapat memberikan harapan baru bagi masyarakat.

Sebuah tantangan bagi umat Islam untuk mengembangkan sistem ekonomi berbasis syari'ah, tantangan itu semakin besar manakala umat Islam melihat realita yang ada bahwa sistem ekonomi dunia saat ini masih dikendalikan oleh sistem ekonomi kapitalis. Umat Islam sendiri masih terpecah belah dalam mengimplementasikan sistem ekonomi Islam, ketidaksamaan persepsi dalam hal pelaksanaan ekonomi islam ketika dijadikan sebuah sistem, ada sebagian yang menganggap urusan agama harus dibedakan dengan urusan ekonomi dan politik, sementara yang lain berpendapat agar agama harus masuk 
dalam segala sektor perekonomian. Perbedaan persepsi dan pendapat itu memungkinkan terjadi karena penamaan ekonomi Islam termasuk katagori baru sehingga perlu adanya waktu sosialisasi dan pengarahan untuk meyakinkan semua kalangan akan pentingnya perubahan system ekonomi. ${ }^{1}$

Dari latar belakang diatas maka penulis memfokuskan pembahasan sebagai berikut: realitas sistem ekonomi kapitalis, realitas sistem ekonomi sosialis, pengertian dan dinamika sistem ekonomi Islam, tujuan dan prinsip sistem ekonomi Islam. Tujuan yang ingin dicapai yaitu untuk membahas pengertian dan realitas kapitalisme, sosialisme, sistem ekonomi Islam, prinsip beserta tujuan dalam ekonomi Islam.

\section{SISTEM EKONOMI}

Sistem ekonomi adalah sekumpulan perangkat atau alat yang terdiri dari unit dan agen ekonomi serta terdiri dari lembaga-lembaga yang membidangi ekonomi dimana antara lembaga tersebut saling berinteraksi dan terintegrasi dengan berbagai lembaga lainnya. ${ }^{2}$

Sedangkan menurut Gilarso, pengertian sistem ekonomi yaitu keseluruhan tata cara dalam rangka mengoordinasikan perilaku produsen, konsumen, distributor agar menjalankan kegiatan ekonomi

${ }^{1}$ Kholil, Muhdi. "Isu Global Perekonomian Islam: Telaah Kritis Terhadap Tata Kelola dan Aktivitas Lembaga-lembaga Keuangan Islam", jurnal ekonomi syariah Indonesia, Vol 1, No 2 (2011).

2 Prathama Rahardja dan Mandala Manurung, Pengantar llmu Ekonomi (Mikroekonomi \& Makroekonomi) Ed-3 (Jakarta: Lembaga Penerbit Fakultas Ekonomi Universitas Indonesia, 2008), 464 
baik produksi, distribusi dan konsumsi serta investasi sehingga membentuk pola kegiatan yang dinamis dan terarah.

Sistem ekonomi merupakan sebuah landasan pijak dalam menjalankan kegiatan-kegiatan ekonomi (produksi, distribusi, konsumsi dan investasi) sehingga tercipta suatu perekonomian yang teratur, terarah sesuai dengan tujuannya. Penggunaan sistem ekonomi tidak terlepas dari adanya sumber daya yang terbatas dalam ilmu ekonomi disebut dengan kelangkaan, karena adanya kelangkaan inilah setiap manusia harus menyelesaikan masalah-masalah pokok ekonomi yang terdiri dari what, how, dan for whom.

Dalam Islam, sistem ekonomi merupakan praktek ekonomi yang dilaksanakan oleh individu, kelompok, keluarga, masyarakat ataupun pemerintah dalam rangka memanfaatkan seluruh sumber daya untuk di produksi menjadi barang dan jasa yang sesuai dengan kaidahkaidah Islam.

\section{REALITAS SISTEM EKONOMI KAPITALIS}

Sistem ekonomi kapitalis tidak lepas dari paham liberalism yang berkembang di eropa pada abad 18, lahir sebagai respon atas diktatorisme para kaum feodal dan gereja waktu itu. Kaum feodal menguasai segala sektor kehidupan mulai dari politik, sosial dan ekonomi. Demikian juga gereja yang memiliki kekuasaan luas untuk melakukan tindakan inkuisisi terhadap siapa saja yang menantangnya. Dari sinilah muncul perlawanan-perlawanan yang dilakukan oleh rakyat kecil yang menuntut persamaan, kebebasan dan keadilan, inilah yang kemudian melahirkan liberalisme dalam bidang politik, 
kapitalisme dalam ekonomi, hidonisme dalam tataran sosio kultural, dan free value dalam ilmu pengetahuan. Hal ini tercantum dalam revolusi perancis yang memiliki semboyan liberty, fraternity, dan equality.

Nawawi mengatakan bahwa Kapitalisme merupakan suatu paham yang diyakini oleh pemilik modal untuk bisa melakukan usahanya dengan bebas untuk meraih keuntungan sebesar-besarnya. Sementara itu pemerintah hanya melakukan intervensi pada kepentingan yang berdifat pribadi. Selanjutnya Milton $\mathrm{H}$ mendefinisikan kapitalisme sebagai suatu system ekonomi yang memberikan kebebasan penuh bagi para pelaku ekonomi untuk melakukan kegiatan-kegiatan dalam mengelola sumber daya untuk kepentingan diri sendiri, pada sistem ekonomi ini terdapat keleluasaan penuh bagi perseorangan untuk memiliki sumber daya. ${ }^{3}$

Ekonomi kapitalis semakin membuktikan kegigihannya dalam memberlakukan kegiatan sesuai dengan ide-ide yang di ajarkan oleh inisiatornya yaitu Adam Smith melalui maha karyanya sebuah buku pertama yang berbicara tentang mekanisme pasar adalah The Theory of Moral Sentiments yang terbit 1759 dan yang kedua berjudul An Inquiry the Nature and Cause of the Wealth of Nation, buku yang diterbitkan pada tahun 1977 ini menjadi karya fenominal dan andalan kapitalis dalam mengaktualisasikan sistem ekonominya. Dalam buku tersebut di berikan kebebasan bagi masyarakat untuk bekerja dan berusaha secara bebas tanpa adanya intervensi dari pemerintah, seyogyanya dalam menerapkan sistem ekonomi kapitalis suatu negara dapat

${ }^{3}$ Ibid., 469 
memanfaatkan sumber daya dengan lebih efisien dan efektif dan dapat meningkatkan kreatifitas masyarakatnya, akan tetapi dalam realitasnya sistem ekonomi kapitalis tidak bisa mengalokasikan dan gagal memanfaatkan sumber daya secara efektif dan efisien hal ini di sebabkan tidak memperhitungkan kebutuhan orang lain dalam menjalankan usahanya. ${ }^{4}$

Berkisar tahun 1200 an beberapa kasus krisis moneter terjadi di berbagai negara, hal ini disebutkan oleh Roy Davies dan Glyn Davies dalam bukunya yang berjudul "The History of Money From Ancient Time of Present Day. Fakta ini menunjukan bahwa sistem ekonomi kapitalis mengakibatka penderitaan bagi ribuan juta manusia. Beberapa contoh konkrit kegagalan ekonomi kapitalis mengangkat perekonomian negara seperti, AIG sebuah perusahaan yang bergerak dibidang asuransi meminta bantuan dana sebesar $40 \mathrm{M}$ dolar Amerika demi mengelakkan perusahaanya dari kepailitan, perusahaan perkreditan rakyat Fannie mae dan freddie mac yang sudah memberikan garansi utang sebesar 5.3 T pun bangkrut. Pada saat presiden Amerika Serikat George W. Bush mendekati masa akhir jabatannya masih harus memberikan uang sebesar $200 \mathrm{M}$ demi meyelamatkan dua perusahaan besar yang sudah hampir lumpuh.

Meskipun demikian ada beberapa kelebihan dari ekonomi kapitalis salah satunya adalah kebebasan ekonomi yang dianut ekonomi kapitalis dapat membuat masyarakat mempunyai banyak

${ }^{4}$ Deliarnov, Perkembangan Pemikiran Ekonomi, edisi ke-3 (Jakarta: Rajagrafindo Persada, 2015), 29. 
kesempatan dalam memenuhi segala kebutuhannya. ${ }^{5}$ Akan tetapi dalam realitanya sistem ekonomi kapitalis bukan hanya menciptakan sebuah sistem ekonomi yang mengutamakan orang-orang yang punya modal akan tetapi juga membuat jurang pemisah yang sangat dalam tataran strata sosial.

\section{REALITAS SISTEM EKONOMI SOSIALIS.}

Sosialisme didefinisikan sebagai suatu sistem ekonomi yang menekankan pentingnya peranan komersial dan kebijakan terpusat dalam menguasai alat-alat produksi dan distribusi barang. Negara dengan sistem sosialisme bertindak sebagai aktor intelektual yang menguasai dalam segala macam bentuk kebijakan atau teori yang bertujuan untuk memperoleh penyaluran barang yang lebih dominan dengan menggunakan tindakan otoriter dari pemerintah pusat.

Sosialisme diartikan sebagai suatu system perekonomian yang di komandani oleh pemerintah dalam melaksanakan kegiatan ekonomi seperti pertambangan, jembatan serta berbagai cabang ekonomi lainnya. Definisi lain menyebutkan system ekonomi sosialisme merupakan seluruh sumber daya di kuasai oleh Negara dan menghapus kepemilikan swasta. ${ }^{6}$

Kemunculan sosialisme sendiri terjadi sekitar abad ke 19 ditandai dengan munculnya buku The Communist Manifesto karangan Karl Mark yang merupakan tokoh sosialis Jerman, Karl Mark berhasil

${ }^{5}$ M Abdul Mannan, Teori dan Praktek Ekonomi Islam (Yogyakarta: PT. Dana Bhakti Wakaf, 1995), 315.

${ }^{6}$ Deliarnov, Perkembangan Pemikiran Ekonomi (Jakarta : Rajagrafindo Persada, 2015), 62. 
membangkitkan semangat persaudaraan antar buruh dan kaum intelektual yang telah terkekang lebih dari se abad lamanya dikarenakan system kapitalisme, Mark berpendapat bahwa system kepemilikan pribadi yang terjadi pada system ekonomi kapitalis harus di hapuskan yang selama ini di kuasai oleh kaum kapitalis, Mark berhasil memporak-porandakan dasar system kapitalis atau system kebebasan natural yang di dirikan Adam Smith. ${ }^{7}$

Dengan munculnya ide dari Karl Mark tersebut mulai bermunculan para pakar untuk membela rakyat serta menyuarakan tentang persamaan hak bagi seluruh lapisan masyarakat, secara kasat mata ekonomi sosialisme mempunyai cita-cita yang mulia dalam perekonomian yaitu system ekonomi yang berlandaskan kebersamaan dan kolektivitas pada semua lapisan masyarakat, perekonomian ini juga merefleksikan komando dari pemerintah dalam melaksanakan roda perekonomiannya, maka dari itu system ekonomi sosialisme juga dikenal dengan sebutan system ekonomi komando yang merujuk pada pelaksanaan dan kebijakan-kebijakan yang di ambil dari keputusan pemerintah. ${ }^{8}$ Dengan adanya system ini membuat buyar system ekonomi yang hanya dikuasai oleh segelintir orang yang mempunyai modal yang banyak serta mempunyai sifat ketamakan dan kerakusan individu.

System ekonomi sosialis yang mulanya diangkap win-win solution untuk mensejahterakan masyarakat dalam suatu Negara malah

7 Ibid., 63.

${ }^{8}$ Rozalinda, Ekonomi Islam Teori dan Aplikasinya Pada Aktivitas Ekonomi (Jakarta: Raja Grafindo Persada, 2014), 30. 
menjadi senjata makan tuan yang kenyataannya belum bisa menyelesaikan permasalahan-permasalahan yang sama dengan sisem ekonomi kapitalis yang terjadi berbanding terbalik dengan cita-cita yang diagung-agungkan sosialisme tentang konsep perkonomian, yang ada adalah munculnya masalah baru yaitu penghapusan hak milik pribadi terhadap alat produksi, sehingga sosialisme menjdi sinonim bagi stagnasi, inefisiensi, birokratisme, mumpungisme dan korupsi. Sekaligus penyakit tradisional negara birokrat mencolok: keangkuhan penguasa, ketidak pedulian penderitaan masyarakat, karena yang dipikirkan buka pemuasan kebutuhan rakyatnya melainkan rencana pusat.

Sosialisme beranggapan bahwa pasar bebas dan tidakadanya pengendali yang sudah menjadi genuine kapitalisme akan menjadikan keberpihakan kepada kaum kapital. Alokasi sumber daya akan dijadikan oleh kaum kapital sebagai dasar untuk mempatenkan pendapatan dan kekayaan untuk diri sendiri. Beberap kritik pun bermunculan ketika system ekonomi sosialis dianggap sebagai sebuah system ekonomi yang lebih baik dari sistem kapitalis, realita yang ada ternyata sosialisme tidak bisa menjadikan masyarakat yang sejahtera. Kritik yang demikian itu bukan tanpa dasar dan tujuan melainkan mempunyai harapan agar masa depan masyarakat dapat lebih adil, bebas dari konflik kelas.

\section{DINAMIKA DAN PENGERTIAN EKONOMI ISLAM}

Sistem ekonomi Islam diakui oleh para pakar ekonomi sebagai sebuah sistem yang memiliki akar yang kuat dimana kemunculannya dimulai 
di Arab yaitu masa-masa awal Islam ketika Rasulullah menerima wahyu dengan Al-Qur'an dan Haditsnya sampai pada masa puncak peradaban Islam dimana Al-Qur'an dan Hadits menjadi pondasi bagi pemikiran ekonomi, masa ini belangsung antara 610-632 H. ${ }^{9}$ Dalam konteks ini, Al-Qur'an dan Hadits merupakan foundational framework yang kuat karena Al-Qur'an menjadi media antara Allah dengan masnusia melalui Rasulullah, secara fungsional, teks spritual ini bukan hanya merupakan kitab suci, melainkan juga menjadi sumber hukum yang absolute, ${ }^{10}$ yang dapat menjawab segala persoalan-persoalan ekonomi secara menyeluruh.

Dilanjutkan dengan kepemimpinan para sahabat Nabi mulai dari tahun 632-661 tetap berpedomanpada Al-Qur'an dan Hadits disertai dengan ijtihad yang luar biasa cemerlang dari penerus-penerus Rasulullah tersebut. ${ }^{11}$ Perkembangan Islam semakin mengalami kemajuan pada masa dinasti Umayyah dengan berubahnya pola kehidupan primitive menjadi masyarakat yang lebih maju dimana perubahan tersebut dimbangi dengan luasnya wilayah taklukan pemerintaan Islam, perubahan-perubahan ini memunculkan keniscayaan terhadap berubahnya kebijakan-kebijakan yang lebih inovatif di berbagai bidang ternasuk bidang ekonomi.

Dilanjutkan dengan pemerintahan dinasti Abbasiyah, keberadaan system ekonomi islam yang inovatif semakin jelas

${ }^{9}$ Ahmed El-Ashker dan Rodney Wilson, Islamic Economics: A Short History (Leiden: Koninklijke Brill NV, 2006), 91.

${ }^{10}$ Hak, N, Ekonomi Islam Hukum Bisnis Syari'a, (Jogjakarta: Teras, 2011)

${ }^{11}$ Ahmed El-Ashker dan Rodney Wilson, Islamic Economics: A Short History, 92-105. 
keunggulannya hal ini ditandai dengan banyaknya karya-karya keilmuan bidang ekonomi yang di karang oleh para pemikir Islam, diantaranya adalah Abu Yusuf, al-Syaibani, Abu Ubaid dan Abdullah bin Harits. Para pemikir ekonomi juga banyak bermunculan meskipun dinasti Abbasiyah berada di ambang kehancuran seperti al-Mawardi, al-Ashfahani, al-Ghazali, al-Dimasyqi, ibnu al-ukhuwwah, ibnu Taymiyah dan ibnu Khaldun. Hal ini menunjukkan bahwa bidang ekonomi mejadi perhatian serius dari para pemikir Islam untuk menyebarkan dan memberikan pengetahuan tentang ilmu ekonomi.

Namun demikian, meskipun secara historis telah tumbuh sejak awal keberadaan Islam, ilmu ekonomi Islam belum dapat dianggap sebagai ilmu yang berdiri sendiri, terutama berkaitan dengan kelengkapan kerangka studinya yang spesifik dan maju, dengan alasan sebagai berikut: (1) Pada masa itu belum membutuhkan kajian ekonomi yang mendesak disebabkan masih sangat sederhananya permasalahan-permasalahan ekonomi yang terjadi. (2) Belum adanya kajian dan diskusi yang bertemakan ekonomi secara khusus dan sistematis meskipun sudah ada karya-karya dari para ilmuan muslim. Indikasi belum tersistematisnya kajian ekonomi pada masa itu adalah karya-karya yang bertemakan ekonomi masih berserakan diberbagai kitab-kitab klasik dengan pendekatan yang berbeda-beda sehingga belum terklasifikasikan secara khusus kitab tentang ekonomi. (3) Faktor kemunduran peradaban Islam di berbagai daerah terutama 
kekuasaan Islam bagian timur seperti Baghdad dan kekuasaan Islam bagian barat seperti Granada ${ }^{12}$

Dari faktor-faktor diatas, factor yang ketiga merupakan factor yang menentukan dalam perkembangan ekonomi Islam selanjutnya yang membawa umat Islam memasuki masa transisi pemikiran ekonomi Islam menuju pemikiran ekonomi Islam kontemporer. Pada masa transisi ini sudah mulai ada kajian-kajian khusus tentang ekonomi Islam, diantaranya tentang: (1) Kajian tentang uang yang di eksplorasi ulang terhadap Al-Qur'an dan Hadits. (2) Melakukan evaluasi kembali terhadap model intelektual Islam serta hubungannya yang disesuaikan dengan kondisi kehidupan umat Islam. (3) Melakukan identifikasi terhadap tantangan yang muncul dari bangsa barat serta mencari alternatif pemecahan masalahnya dengan menggunakan perspektif intelektual Islam. ${ }^{13}$

Perkembangan ekonomi Islam kontemporer semakin menunjukkan eksestensinya, terbukti dengan banyaknya kontribusi para pemikir Islam terhadap pentingnya ekonomi Islam, seperti alMaududi, Baqir al-Sadr dan lain sebagainya yang muncul pada masa sebelum tahun 1970-an, meskipun karya-karya mereka masih bersifat umum, kurang menggunakan karangka ekonomi dan lebih banyak menyerang pandangan orang-orang barat tentang kapitalisme dan sosialisme.

${ }^{12}$ M. Abdul Karim, Sejarah Pemikiran dan Peradaban Islam, Cet. 1. (Yogyakarta: Pustaka Book Publisher, 2007), 161-253.

${ }^{13}$ Ibid., 161. 
Konferensi ilmu ekonomi islam pertama yang diadakan di mekkah pada tahun 1976 merupakan awal dari kemajuan ekonomi Islam karena sudah menggunakan pendekatan ekonomi standart, menggunakan analisa matematika, ekonometrika dan lain sebagainya sehingga dapat digunakan untuk menjawab persoalan-persoalan yang timbul dari level mikro dan makro.

Ekonomi Islam diartikan sebagai ilmu yang membahas tentang perilaku-perilaku manusia dalam memenuhi kebutuhan hidupnya dengan berlandaskan pada kaidah-kaidah agama Islam. Islamic economic aims the study of human falah (well-being) achieved by organizing the resources of the eart on the basic of cooperation and participantion (ilmu ekonomi Islam ertujuan untuk melakukan kajian tentang mencapai kebahagiaan hidup manusia dengan cara mengorganisasikan sumber daya dengan berlandaskan gotong royong dan kebersamaan).

Selain pengertian diatas, Umar Chapra mengemukakan bahwa Islamic economic was defined as that branch of knowledge wich helpe realize human well being through and allocation and distribution of scarce resources that is in conformity with islamic teachins whitout unduly curbing individual freedom or creating continued macro economi an ecological imbalances. ${ }^{14}$

Ekonomi rabbani mempunyai arti ekonomi Islam sebagai ekonomi ilahiyah, disinilah letak perbedaan mendasar sistem ekonomi konvensional dengan ekonomi Islam, dalam ekonomi konvensional

${ }^{14}$ Ai Siti Farida, Sistem Ekonomi Indonesia (Bandung: CV. Pustaka Setia, 2011), 55 . 
lebih menekankan pada urusan materi dan keuntungan yang bersifat duniawi dan individualis, sedangkan ekonomi Islam terdapat proses integrasi antara keuntungan duniawi dengan ukhrawi yang diyakini oleh umat Islam sebagai kehidupan yang balance antar keduanya, ada aturan yang harus dilakukan dalam menjalankan ekonomi berbasis rabbani, yaitu tidak melakukan transaksi yang haram baik dzat dan akadnya seperti melakukan Ikhtikar, gahrar, maysir, rekayasa permintaan, rekayasa pasar, risywah dan lain sebagainya.

Ekonomi akhlak mempunyai arti tidak diperbolehkannya melakukan kegiatan ekonomi dengan cara memanfaatkan orang lain demi kepentingan diri sendiri dan tidak adanya kelompok yang lebih menguasai sumber daya ekonomi, kegiatan yang dimaksud berupa kegiatan produksi, distribusi, dan konsumsi.

Sedangkan ekonomi pemberdayaan merupakan kegiatan ekonomi yang bertujuan merealisasikan kehidupan yang saling membutuhkan antar umat manusia dalam rangka memenuhi kebutuhannya yang sesuai dengan ketentuan syariat Islam. Dalam memberdayakan ekonomi manusia haruslah bisa berbagi dengan orang lain. Selain itu ekonomi pemberdayaan merupakan sarana manusia dalam mengaktualisasikan ilmu yang telah diberikan oleh Allah dengan nilai-nilai kemanusiaanya. Nilai-nilai kemanusiaan tersebut dijadikan dasar dalam ekonomi Islam untuk memerdekakan serta memuliakan manusia dan memberikan rasa keadilan, nilai tersebut direalisasikan dengan dengan rasa $u k h u w a h$ antar sesama manusia.

Ekonomi Islam dalam menjalankan kegiatan berpegang teguh pada fondasi yang kuat, yaitu: (1) Tauhid. Dalam sistem ekonomi 
Islam segala sesuatu yang dilakukan oleh manusia dalam memenuhi kebutuhannya harus ada nilai-nilai rabbaniyah. Sehingga semua aktifitas ekonomi yang dilakukan tidak mengandung hal yang tidak dikehendaki oleh Allah Subhanahu wa ta'ala dan terus berusaha meningkatkan keimanan dan ketakwaan dengan cara melakukan yang diperintahkan dan menjahui yang dilarang. (2) Maslahah. Maslahah disini berbeda dengan utility. Utility diartikan sebagai keinginan seseorang untuk mencapai sesuatu dalam aspek materi yang hal tersebut diperuntukkan bagi diri orang itu sendiri tanpa memperdulikan orang lain. Sedangkan maslahah merupakan suatu konsep kepuasan yang diperoleh oleh seorang Muslim, dimana pada saat ia mamperoleh suatu kenikmatan tersebut ia bersyukur pada tingkatan yang paling tinggi, yaitu dengan memberikan sebagian dari kenikmatan yang telah ia peroleh untuk disedekahkan kepada orang lain yang membutuhkan. ${ }^{15}$

(3) Sebagai kholifah dimuka bumi. Manusia ditugaskan oleh Allah Subhanahu wa Ta'ala sejak berada di dalam kandungan sampai menginjakkan kakinya di bumi Allah untuk menjadi seorang khalifah/pemimpin. Manusia sebagai khalifah/pemimpin harus mampu untuk menuntun dirinya kepada suatu kebaikan bukan malah sebaliknya yaitu terjerumus kepada sesuatu yang dilarang oleh Allah Swt. Seorang pemimpin harus mempunyai rasa tanggungjawab dan juga harus mampu berlaku adil kepada siapapun tanpa terkecuali. Selain itu, tugas khalifah/pemimpin adalah mampu untuk melestarikan alam, memanfaatkannya, serta mampu untuk mengelola apa yang telah tersedia di alam dengan sebaik mungkin agar mampu mewujudkan

${ }^{15}$ Ibid., 18. 
kesejahteraan di setiap umat manusia serta makhluk hidup lainnya. Kewajiban manusia tidak hanya bertumpu pada masalah dunia saja, namun juga harus mampu untuk senantiasa mendekatkan diri, serta menjalankan segala perintah Allah Subhanahu Wa Ta'ala dengan penuh keikhlasan dan kekhusyukan.

(4) Tujuan hidup adalah kebahagiaan di dunia dan di akhirat. Manusia hidup tidak hanya terbatas pada kehidupan dunia saja, namun terdapat kehidupan di luar dunia, yaitu kehidupan akhirat. Oleh karena itu, dalam setiap tahapan kehidupan tersebut manusia hendaknya dapat mencapai keberhasilan. Keberhasilan tersebut tidak hanya bersifat duniawi saja, namun kita juga harus mmapu untuk mencapai keberhasilan kelak ketika kita telah berada di akhirat, untuk mencapai itu perlu senantiasa melakukan kebaikan dan kebajikan dalam hidupnya serta bersyukur pada Allah subhanahu wa Ta'ala. (5) Instrument pengatur ekonomi. Ekonomi Islam mempunya beberapa instrumen yang menjadi pengatur jalannya ekonomi yaitu, zakat, infaq dan shadaqah, waqaf/waris, anti riba/judi/gharar. Instrument ekonomi adalah sesuatu yang mampu digunakan untuk mengatur jalannya aktivitas ekonomi. ${ }^{16}$ (6) Technological constraint, akhlak control on consumption and production. Hambatan teknologi merupakan suatu yang yang sampai saat ini masih dirasakan oleh sebagian masyarakat. Terlepas dari dampak buruk yang ditimbulkan oleh teknologi, saat ini teknologi telah memberikan kontribusi bagi kehidupan umat manusia menjadi lebih maju, lebih efektif dan efisien. Oleh karena itu, masyarakat harus mampu memanfaatkan teknologi bagi aktivitas

\footnotetext{
${ }^{16}$ Ibid., 20.
} 
kehidupannya yang dapat menopang tercapainya kehidupan yang maju, namun tetap berpegang pada nilai-nilai agama.

\section{PILAR EKONOMI ISLAM}

Sehubungan dengan filsafat aliran kehidupan. Ada tiga hal penting yang menjadi pilar dalam berjalannya sistem ekonomi Islam. Ketiga pilar inilah yang menunjukkan adanya sistem kehidupan ekonomi. Sistem ekonomi Islam akan hidup jika di dalamnya ada sesuatu yang mengalir.

Jika di dalam tubuh manusia, darah dapat mengalir dengan baik bila alat pemompa darah bekerja secara optimal. Alat pemompa darah dalam tubuh manusia adalah "jantung”. Sama hal nya dengan sistem ekonomi Islam di dalamnya juga terdapat suatu sistem kerja jantung secara optimal. Jantung dalam sistem ekonomi Islam terdapat instrumen-instrumen yang dapat menggerakkan aktivitas ekonomi, yaitu aktivitas sektor riil dan sektor moneter. Ketiga pilar yang menjadi jantung dalam sistem ekonomi Islam adalah: (1) Zakat, Infaq, Shadaqah, Wakaf dan Waris, (2) Anti riba, dan (3) Anti judi. Ketiga pilar tersebut merupakan pilar penting yang dapat menggerakkan jalannya sektor moneter dan sektor riil. Sektor moneter dan sektor riil dapat menjadikan ekonomi berjalan dengan sempurna. Tidak akan terjadi ketimpangan yang menyebabkan salah satu sektor bergerak, sementara sektor yang lainnya tidak bergerak, sektor moneter dan sektor riil itu mempunyai huungan yang erat. 
Tujuan dan hikmah diperintahkannya zakat sebagai berikut; membantu fakir miskin dan mengangkat derajatnya, membantu memecahkan masalah-masala yang dihadapi mustahiq zakat, mempererat silaturrahim sesama umat manusia, menghilangkan dan membersihkan sifat kikir, dengki dan iri. ${ }^{17}$ Khaf menjelaskan konsumsi agregat mestinya dioptimalkan dengan meningkatkan konsumsi dari masyarakat miskin. Hal ini bisa dilakukan dengan mengoptimalkan pendapatan dari masyarakat muslim yang diperoleh dari multiplayer efek zakat dalam upaya pemerataan pendapatan masyarakat. Ketika pemerataan terjadi maka, tingkat konsumsi kebutuhan dasar akan meningkat dari semua lapisan masyarakat. Dalam masyarakat yang konsumsi agregatnya diperoleh dari produksi domestik juga akan membawa dampak pada multiplayer effek produksi dan investasi. Naiknya produksi ini akan berdampak dalam mengurangi pengangguran, mampu meningkatkan dan melakukan pemerataan pendapatan dan tentunya juga dapat menimbulkan pertumbuhan ekonomi yang semakin meningkat. ${ }^{18}$ Jika dilihat dari sudut pandang ekonomi, zakat banyak memberikan efek dan dampak positif.

Tiga hal penting dari zakat terhadap pengaruh ekonomi, yaitu: (1) Pengaruh zakat pada usaha produktif. Pegeluaran zakat kepada orang-orang berhak menerimanya memiliki pengaruh di bidang ekonomi. Mereka yang menerima zakat akan dimanfaatkan dan kembangkan kembali untuk lebih memenuhi kebutuhannya, baik yang

${ }^{17}$ Muhammad, Ekonomi Moneter Islam (Yogyakarta: UII Press, 2018), 2024.

${ }^{18}$ Sumar'in, Ekonomi Islam (Yogyakarta: Graha Ilmu, 2013), 116. 
berupa barang-barang maupun jasa-jasa. Ini biasanya mempercepat arus konsumsi, meningkatnya konsumsi, menimbulkan usaha untuk berproduksi. (2) Pengaruh zakat dalam mengembalikan pembagian pendapatan. Zakat yang diwajibkan bagi seluruh umat manusia adalah segala harta yang dimilikinya, tentunya kalau syarat-syaratnya terpenuhi, dengan adanya kewajiban zakat tersebut menjadikan zakat sebagai sarana distribusi harta. Zakat juga di lakukan setiap tahun maka zakat itu merupakan alat permanen bagi pengembalian distribusi kekayaan. (3) Pengaruh zakat atas kerja. Zakat dapat menggerakan roda perekeonomian dengan cara memberikan kesempatan bekerja. Zakat hanya diberikan kepada mereka yang tidak mampu berusaha. Artinya, zakat diarahkan kepada kelompok dalam masyarakat yang konsumtif akan menyebabkan meningkatnya permintaan barang, sehingga bertambahlah pula kesempartan-kesempatan kerja yang baru. ${ }^{19}$

Riba merupakan tambahan sesuatu yang diwajibkan oleh pemilik harta pada orang yang meminjam hartanya. Tidak diperbolehkannya riba disebabkan dengan beberapa alasan, diantaranya: sudah ketentuan dari Allah dan Rasul-Nya, membuat sengsara bagi orang yang meminjam, membuat orang yang punya harta malas untuk bekerja, membuat hubungan antar sesame tidak produktif.

Maysir merupakan sebuah bentuk transaksi antara 2 orang atau lebih untuk memperoleh sesuatu yang menguntungkan satu pihak saja dan merugikan pada pihak yang lain denga cara mengaitkan transaksi

19 Abdul Aziz \& Mariyah Ulfah, Kapita Selekta Ekonomi Islam Kontemporer (Bandung: Alfabeta, 2010), 83. 
tersebut dengan suatu kajadian atau tindakan. Maysir disini merupakan permainan yang sangat disukai terutama oleh bangsa Arab dahulu yaitu sebelum masuknya Islam pada masa itu. Pada masa itu maysir atau perjudian dilakukan dengan bertaruh seperti orang pada umumnya. Namun bisa juga dilakukan dengan berlotre unta di depan banyak orang. ${ }^{20}$

Maysir atau perjudian selalu diidentikkan dengan melakukan sesuatu yang gharar. Gharar memang berkaitan dengan masalah ketidakpastian membuat kondisi yang akan dihadapi di masa yang akan mendatang bersifat tidak pasti, dalam ekonomi gharar dapat diartikan sebagai tidak lengkapnya informasi teradap kegiatan perekonomian tersebut.

Dalam bahasa keuangan modern, keberadaan informasi sangat relevan meskipun tidak lengkap untuk memahami dan menilai masa depan agar dapat menerjemahkan suatu ketidakpastian menjadi sebuah risiko. Keputusan yang rasional hanya dapat dibuat pada saat informasinya jelas dan lengkap atau paling tidak dalam kondisi berisiko. Selanjutnya, harus pula diakui bahwa informasi tidak pernah tersedia secara lengkap sehingga risiko hanya dapat diperkirakan dan tidak dapat dihitung secara tepat. ${ }^{21}$

${ }^{20}$ Moenawar Khalil, Kelengkapan Tarikh Nabi Muhammad (Jawa Timur: Gema Insani, 2001), 27.

${ }^{21}$ Muhammad, Ekonomi Moneter Islam (Yogyakarta: UII Press, 2018), 31 


\section{URGENSI SISTEM EKONOMI ISLAM}

Untuk mempraktikan sistem ekonomi Islam harus ada regulator yaitu Negara, Negara memiliki peranan yang sangat penting dalam terealisasinya sistem ekonomi Islam. Adiwarman Karim menilai bahwa pemerintah merupakan pelaku kegiatan-kegiatan ekonomi yang mempunyai peranan sangat penting baik dalam produksi, distribusi dan konsumsi, peran pemerintah seagai regulator dalam kegiatan ekonomi sudah di praktekan oleh Rasulullah. Rasulullah sudah memulai dan memiliki peran penting dalam penyusunan sistem ekonomi dalam hal penerimaan dan pengeluaran negara.

Secara garis besar peran regulator dalam sistem ekonomi Islam digambarkan sebagai berikut: 


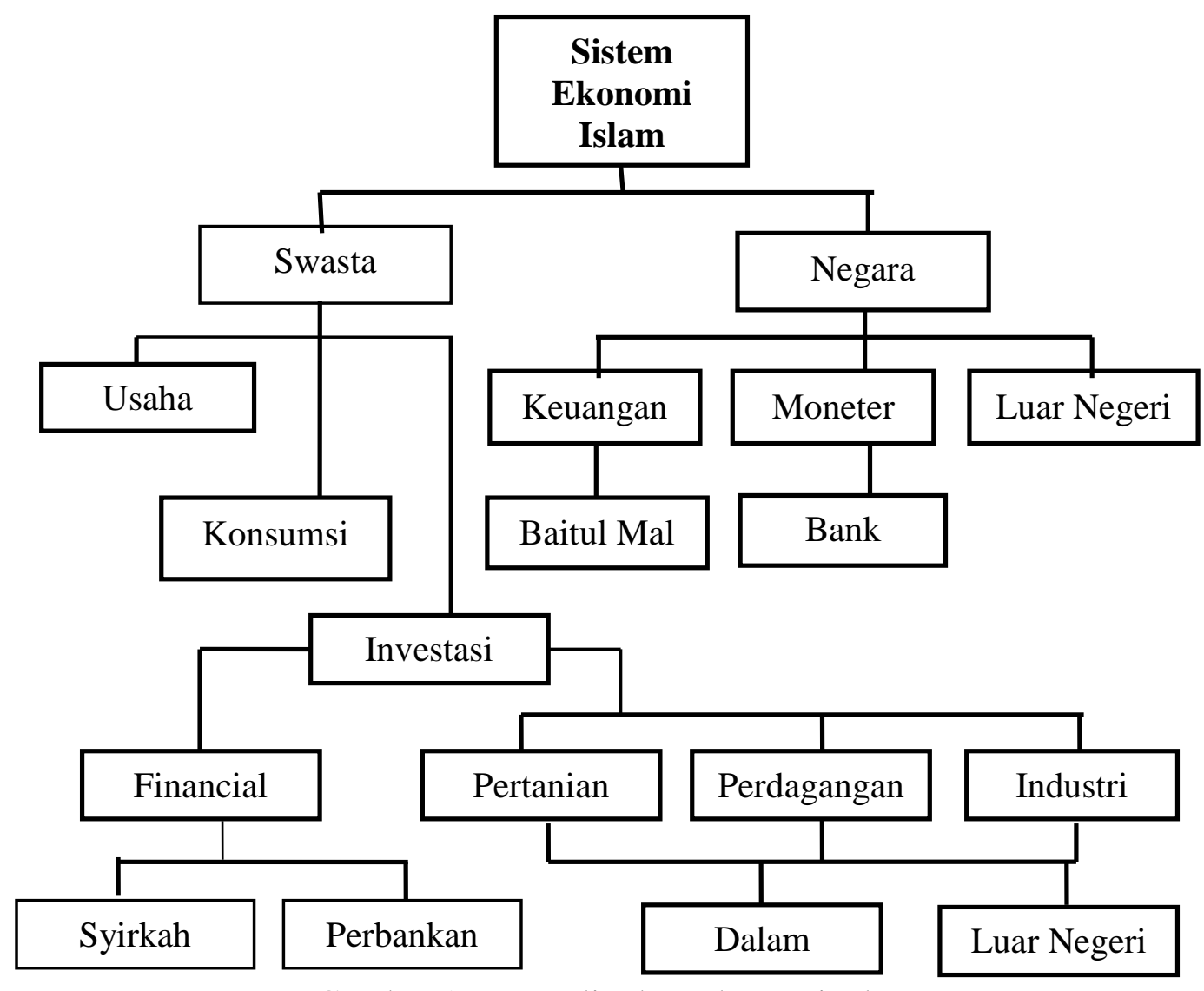

Gambar 1. Ruang lingkup ekonomi Islam

Peran regulator yang sudah dicontohkan oleh Rasulullah dilanjutkan oleh sahabat-sahabat Rasul. Abu Bakar, membuat kebijakan yang mempengaruhi peningkatan agregat demand dan agregat supply yang mempengaruhi terhadap pendapat nasional, selain itu Abu Bakar berhasil memperkecil perbedaan antara orang kaya dengan orang miskin, kebijakan-kebijakan yang dilakukan Abu bakar dilanjutkan oleh Umar dengan tembahan ijtihad yang cemerlang dari sahabat Umar bin Khattab serta dilanjutkan oleh Utsman bin Affan dan Ali bin Abi Thalib. 
Peran regulator inilah yang perlu dijadikan perhatian dalam pengembangan sistem ekonomi Islam. Merupakan bagian dari tugas regulator dalam melaksanakan sistem ekonomi Islam adalah memberikan kebijakan di sektor moneter dan fiskal, yang sudah dilakukan regulator dalam hal ini pemerintah hanya mengupayakan pengambilaan sumber-sumber riil pada laju yang lebih cepat dari yang berkesinambungan pada tingkat harga yang stabil sehingga dapat menimbulkan tingkat inflasi. Lebih dari itu Negara industry utama seperti Jepang, defisit fiskal yang besar telah menjadi sebab kegagalan memenuhi target suplai uang. Hal seperti ini cenderung menjadi beban perjuangan dalam mengahapus inflasi pada kebijakan moneter. Economists Advisory Group Business Research Study menjelaskan "semakin besar ketergantungan pemerintah pada sistem perbankan maka semakin sulit bagi bank sentral untuk melakukan kebijakan moneter yang konsisten".

Kebijakan meminimalisir defisit fiskal harus diupayakan oleh pemerintah akan tetapi kebijakan ini harus juga diikuti dengan faktorfaktor utama yang leih urgen, yaitu: (1) Ketidaksediaan pemerintah untuk meningkatkan pembiayaan yang memadai melalui perpajakan dan sumber-sumber pendapatan non inflasioner lainnya untuk pemenuhan pengeluaran penting lainnya. (2) Kurangnya ketersediaan pemerintah untuk mengeleminasi secara substansial pengeluaran yang tidak produktif. (3) Selain itu perkembangan praktik ekonomi Islam dalam bidang keuangan pada dekade belakangan ini menunjukkan arah positif, hal ini dibuktikan dengan banyaknya lembaga-lembaga keungan berbasis syariah, selama 20 tahun terakhir, sektor perbankan 
dan keuangan Islam mengalami perkembangan sangat pesat. Sudan, Iran, Pakistan telah menjadikan perbankan Islam sebagai hukum Negara. Dibelahan Negara lain, seperti mesir, Malaysia, Brunei Darussalam membuat perbankan bisa berdampingan dengan perbankan konvensional, bahkan sejumlah lembaga keuangan di berbagai Negara mengakui perbankan Islam sebagai peluang dalam memajukan pertumbuhan ekonomi.

Potensi perkembangan sistem ekonomi Islam bukanlah tanpa perhitungan, Vogel dan Heyes mengatakan bahwa sejumlah lembaga keuangan utama di Negara barat, Timur Tengah dan Asia mengakui keunggulan bisnis keuangan Islam mempunyai keunggulan dan peluang yang sangat besar dalam meningkatkan pertumbuhan ekonomi, salah satu keunggulannya adalah populasi penduduk muslim yang banyak terutama di Indonesia, keunggulan kuantitas ini harus menjadi power dalam mengembangkan sistem ekonomi Islam.

Ada beberapa alasan mengapa harus menggunakan sistem ekonomi Islam, yaitu: (1) Religious ideologis. Religious ideologis merupakan sisi fundamental ajaran Islam, sisi ini di lakukan karena adanya keinginan untuk melaksanakan konsep bisnis dan keuangan Islami sebagai jalan hidup, sisi inilah yang membedakan sistem ekonomi Islam dengan sistem ekonomi lainnya. (2) Empiris pragmatis. Hal ini muncul saat kemerdekaan Negara yang awalnya di bawah kolonialisme Negara barat, kemerdekaan Negara tersebut juga memunculkan keinginan merdeka dari sisi ekonomi, ekonomi konvensional dianggap gagal dalam mensejahterakan masyarakat secara umum, ekonomi konvensional lebih banyak dipandang sebagai 
sistem yang memberikan keuntungan pada golongan tertentu. Salah satu bukti keinginan untuk merdeka dalam bidang ekonomi adalah berdirinya Islamic Developmenrt Bank (IDB). (3)Akademik idealis. Dalam kajian akademik ditemukan adanya kesenjangan dan instabilitas ekonomi serta krisis moneter yang ditimbulkan sistem ekonomi konvensional. Hal lain dibidang akademis, sudah ada beberapa universitas seperti Harvard University sudah mulai aktif mengadakan forum dan kajian-kajian tentang ekonomi syariah.

Di jantung sistem ekonomi Islam ada beberapa aturan yang tidak bisa langgar oleh pelaku ekonomi, karena adanya aturan yang abadi tersebut akan mempengaruhi perilaku dan output ekonomi. Sistem ekonomi Islam antara Negara satu dengan Negara yang lainnya sangat bervariasi hal ini dikarenakan adanya peraturan yang bersifat "sekunder", akan tetapi aturan institusi intinya akan selalu sama. Misal, kebijakan luar negerinya tidak sama antar Negara, tetapi institusi kewarisannya tetap sama antara masyarakat Islam satu dengan masyarakat Islam lannya.

Di Indonesia sendiri praktik ekonomi Islam sudah menunjukkan kemajuannya, sejak beberapa tahun terakhir ekonomi Islam sudah menjadi perhartian serius dari berbagai kalangan hal ini dibuktikan dengan semakin banyaknya lembaga-lembaga yang mempraktekan sistem ekonomi Islam baik lembaga keuangan, seperti perbankan, BMT, Koperasi, pasar modal, asuransi, reksadana, pegadaian yang sudah berbasis dan berprinsip syariah. Dengan banyaknya lembaga keuangan tersebut dapat memberikan alternatif bagi masyarakat untuk melakukan transaksi keungannya yang bebas 
dari riba. Di lembaga pendidikan sudah banyak yang menawarkan program studi khusus untuk mengembangkan sistem ekonomi Islam, seperti program studi ekonomi syariah, perbankan syariah dan akuntansi syariah dan lain sebagainya.

Melihat perkembangan ekonomi Islam yang signifikan baik tingkat lokal maupun internasional tersebut, diperlukan berbagai strategi yang lebih jelas dan terarah agar perkembangan dan penerapan sistem ekonomi Islam bisa terwujud sehingga akan tercipta era ekonomi yang berkeadilan, bermoral serta berketuhanan. Abbas Mirakhor berpendapat kajian ekonomi Islam juga harus menggunakan pendekatan hermenuetik yaitu the process of extracting economic meaning from the first order interpretation, dengan menggunakan pendekatan ini ekonomi Islam akan semakin kaya dengan berbagai teori ekonomi yang benar-benar berbasis syariah, yaitu sesuai dengan kaidah dan aturan Islam.

Diantara tantangan yang dihadapi dalam merealisasikan sistem ekonomi Islam khususnya Indonesia adalah masih kurangnya pemahaman masyarakat terhadap sistem keuangan dan perbankan syariah, hal ini dapat dilihat dari belum sadarnya masyarakat dengan mengakses layanan di lembaga keuangan syariah bila dibandingkan dengan lembaga keuangan konvensional, untuk itu perlu adanya sosialisasi yang inten bagi masyarakat, misalnya membangun kerjasama dengan takmir masjid diseluruh daerah untuk memberikan tema khutbah masijid tentang pentingnya ekonomi Islam, serta masjid bisa memberdayakan remas masijid dengan kajian-kajian tentang 
ekonomi Islam lebih bagus lagi apabila ekonomi Islam di praktekan oleh remaja masjid tersebut.

\section{PENUTUP}

Sistem ekonomi Islam menekankan masalah bagaimana cara memperoleh harta kekayaan, pengelolaan harta, serta cara pendistribusian kekayaan tersebut ditengah-tengah manusia agar dapat dicapai kemaslahatan bersama. Dari sinilah dikatan bahwa sistem ekonomi Islam berdiri diatas pilar fundamental utama, yakni menyangkut konsep kepemilikan (Tamalluk), pengelolaan (Tasharruf) serta distribsi kekayaan di tengah masyarakat (tawzi' ats-tsarwah bayna an-nas). Ketiga konsep fundamental tersebut dapat dilakukan oleh peranan negara.

Peranan negara sebagai regulator serta masyarakat dalam perspektif Islam tidak dapat disangsikan lagi, apalagi dalam konteks kehidupan bernegara dewasa ini. Pemerintah memiliki peran penting dalam menentukan arah dan kebijakan ekonomi bagi kesejahteraan rakyatnya, begitu juga rakyat yang menjadi ujung dalam kegiatan ekonomi. Implikasi dari teraturnya aktivitas ekonomi yang dijalankan secara baik oleh pemerintah akan berbuah manis bagi kesejahteraan masyaraktnya. Inilah sebenarnya yang dicita-citakan dalam Islam, terwujudnya keadilan bukan ketimpangan atau kesenjangan. 


\section{DAFTAR RUJUKAN}

Alma, B dan Priansa, DJ. Manajemen Bisnis Syariah. Bandung: Alfabeta, 2011,.

Antonio, Syafii. Islamic Banking dari teori ke praktek, Jakarta: Gema Insani, 2011.

Arif, M. Lembaga Keuangan Syariah. Bandung: Pustaka Setia, 2012.

Aziz, Abdul dan Ulfah, Mariyah. Kapita Selekta Ekonomi Islam Kontemporer. Bandung: Alfabeta, 2010.

Cahyani, Tinuk Dwi. Hukum Waris dalam Islam. Malang: UMM Press, 2018.

Chapra, U. Masa Depan Ilmu Ekonomi Sebuah Persprektif Islam. Jakarta: Gema Insani, 2011.

Deliarnov. Perkembangan Pemikiran Ekonomi. Jakarta: Rajagrafindo Persada, 2015.

El-Ashker, Ahmed dan Wilson, Rodney. Islamic Economics: A Short History. Leiden: Koninklijke Brill NV, 2006.

Farida, Ai Siti. Sistem Ekonomi Indonesia, Bandung, CV. Pustaka Setia, 2011.

Hak, N. Ekonomi Islam Hukum Bisnis Syari'a. Jogjakarta: Teras, 2011. Huda, N. Lembaga Keuangan Islam. Jakarta: Kencana Prenada Media Group, 2010.

Karim, M. Abdul. Sejarah Pemikiran dan Peradaban Islam, Cet. 1. Yogyakarta: Pustaka Book Publisher, 2007.

Khalil, Moenawar. Kelengkapan Tarikh Nabi Muhammad. Jawa Timur: Gema Insani, 2001. 
Khan, A. Economic Massage of The Qur'an. Kuwait: islamic Book Publisher, 1996,

Kholil, Muhdi. "Isu Global Perekonomian Islam: Telaah Kritis Terhadap Tata Kelola dan Aktivitas Lembaga-lembaga Keuangan Islam", jurnal ekonomi syariah Indonesia, Vol 1, No 2 (2011).

Kotler, P. Manajemen Pemasaran. Jakarta: Person Education Asia Pte.Ltd dan PT Prenhallindo, 2000.

Mannan, M. Abdul. Teori dan Praktek Ekonomi Islam. Yogyakarta: PT. Dana Bhakti Wakaf, 1995.

Moleong, L. Metode Penelitian Kualitatif. Bandung: PT. Remaja Rosda Karya, 2001.

Muhammad. Ekonomi Moneter Islam. Yogyakarta: UII Press, 2018.

Nawawi, I. Isu Nalar Ekonomi Islam. Jakarta: Dwiputra Pustaka Jaya, 2013.

Rahardja dan Manurung, Mandala. Pengantar llmu Ekonomi (Mikroekonomi \& Makroekonomi) Ed-3. Jakarta: Lembaga Penerbit Fakultas Ekonomi Universitas Indonesia, 2008.

Rahman, Afzalur. Doktrin Ekonomi Islam, ter. Nastangin dan Soeroyo, Jilid I. Yogyakarta: Dana Bhakti Wakaf, 1995.

Rivai, V. Firmansyah, R. Veithzal, AD. Rizqullah. Islamic Financial Management, Bogor, Ghalia Indonesia, 2010.

Rivai, V. Islamic Marketing. Jakarta: Gramedia Pustaka Utama, 2012.

Rozalinda. Ekonomi Islam Teori dan Aplikasinya Pada Aktivitas Ekonomi. Jakarta: Raja Grafindo Persada, 2014. 
Sudarsono, Heri. Konsep Ekonomi Islam: Suatu Pengantar. Yogyakarta: EKONSIA, 2002.

Sule, ET dan Saefullah, K. Pengantar Manajemen. Jakarta: Prenada Media Group, 2012.

Sumar'in. Ekonomi Islam. Yogyakarta: Graha Ilmu, 2013.

Yusanto, Ismail dan Yunus, Arif. Pengantar Ekonomi Islam. Bogor: Al-Azhar Pres, 2009. 